\author{
Natalia Iwaszczuk \\ AGH University of Science and Technology \\ 30 Mickiewicza av., Krakow, 30-059, Poland, natalia.iwaszczuk@gmail.com \\ https://orcid.org/0000-0002-7816-115X \\ Marta Szyba \\ AGH University of Science and Technology \\ 30 Mickiewicza av., Krakow, 30-059, Poland, marta.szyba@gmail.com \\ (1) https://orcid.org/0000-0002-6340-3232 \\ Myroslava Mylenka \\ Vasyl Stefanyk, Precarpathian National University \\ 57 Shevchenko Str., Ivano-Frankivsk, 76018, Ukraine, mulenka.m@gmail.com
}

\title{
USING ALTERNATIVE SOURCES OF METHANE FOR ENERGY AS A METHOD OF ENVIRONMENTAL PROTECTION AND IMPROVEMENT OF ECONOMY CONDITION, ON EXAMPLE OF POLAND
}

\begin{abstract}
The article analyses the types of waste generated in economy and the possibilities of their management, on the example of Poland. The main focus was on using selected types of waste for methane production. The impact of the decomposing mass of organic waste on the production of greenhouse gases was examined and various types of biogas plants operating in Poland were presented (biogas plants at landfills, biogas plants at sewage treatment plants, agricultural biogas plants). The article also presents the benefits for the economy from the use of methane from methane drainage. Unfortunately, in Poland, methane resources are used to a small extent. In the case of mines, landfills or sewage treatment plants it is related to high costs of constructing methane capture installations, which are not offset by revenues from sales of gas and green certificates. Although much more favourable blue certificates have been introduced for agricultural biogas plants, the obstacle standing in the way of their progress is the lack of local spatial development plans for the places designated for their construction.
\end{abstract}

\section{Keywords}

energy management, environmental protection, greenhouse gases, methane, municipal and agri-food waste, biogas

\section{Nomenclature, Abbreviations}

CSO - Central Statistical Office, EU - European Union, GHG - Greenhouse gas, CCS - Carbon Capture and Storage, GDP - Gross Domestic Product, TGE - Towarowa Giełda Energii (eng. Polish Power Exchange), UV - ultraviolet, TGCs - Tradable Green Certificates system, TREC - Tradable Renewable Energy Certificates, RES - renewable energy sources, PRM - Property Rights Market, $\eta$ - efficiency

\section{Introduction}

Since the dawn of time, man has had an impact on the environment. However, recently this impact has become more and more noticeable due to the ever-growing human population, progress in its development and the desire to increase the quality of life. As a result, the demand for food and industrial products increases, the production of which is very material- and energy-consuming. There is also a growing demand for energy, which is still obtained mainly from fossil fuels in the process of combustion of which carbon dioxide $\left(\mathrm{CO}_{2}\right)$ and other gases responsible for global warming (so-called greenhouse gases) are emitted to the atmosphere. In order to decrease their emissions, efforts are made to reduce the energy consumption of products and processes, as well as to use renewable and alternative energy sources for energy purposes. In order to reduce carbon dioxide emissions, the European Union requires Member States to ensure that the share of energy obtained from renewable sources in 2020 is not less than $15 \%$ in the total energy consumption of these countries [1].

The EU's climate and energy policy for 2021-2030 introduces higher requirements regarding [2]:

- reduction of greenhouse emissions (by at least 40\% compared to 1990),

- increasing the share of energy from renewable sources (up to $32 \%$ ), 
- $\quad$ increasing energy efficiency (by at least 32.5\%).

Going even further in its plans (until 2050), the European Commission has agreed to reduce greenhouse gas emissions to net zero (introducing so-called climate neutrality) and started a discussion on changing to more ambitious emission reduction targets by 2030 [3].

„The European Commission's vision outlines seven main strategic building blocks:

- maximise the benefits of energy efficiency, including zero emission buildings;

- maximise the deployment of renewables and the use of electricity to fully decarbonise Europe's energy supply;

- embrace clean, safe and connected mobility;

- a competitive EU industry and the circular economy as a key enabler to reduce GHG emissions;

- develop an adequate smart network infrastructure and interconnections;

- reap the full benefits of bioeconomy and create essential carbon sinks;

- $\quad$ tackle remaining $\mathrm{CO}_{2}$ emissions with Carbon Capture and Storage (CCS)" [4].

Still, the main focus of EU and international organizations dealing with the problem of global warming remains on reducing $\mathrm{CO}_{2}$ emissions. While focusing on carbon dioxide, less attention is paid to emissions of another dangerous greenhouse gas into the atmosphere - methane, which is separated from fossil fuel deposits during their exploitation (e.g. hard coal and brown coal) or is formed during uncontrolled anaerobic digestion of an organic substance, which is classified as waste in agriculture and animal husbandry as well as agri-food processing. Methane is the basic component of natural gas (also known as high-methane gas) extracted from the Earth's interior, which is used for various economic purposes, mainly energy. It is also found in coal deposits, during exploitation of which it is released. Due to the explosive nature of its mixture with air, it poses a huge threat to the safety of miners. Methane is also produced as a result of anaerobic fermentation of organic matter, and if it occurs uncontrollably it escapes into the atmosphere, reinforcing the greenhouse effect, because its carbon equivalent is 25 . Technical progress in recent decades, on the other hand, has resulted in the containment of the released methane in some cases and in using it (as an alternative source) for energy production. In order to obtain gas, the mines carry out degassing of deposits and recover them from air ventilating in mine workings. Methane is also a basic component of biogas (45-70\%) obtained from municipal waste landfills, sewage treatment plants and agricultural biogas plants. Biogas is most often burned in cogeneration units producing energy and heat, efficiency of which can be up to $90 \%$. A particular feature of methane is that it is considered the most ecological fossil source of primary energy. That is why its development is so important, especially when it goes hand in hand with a positive effect for environmental protection. The purpose of this article is: to examine the production potential of the Polish economy in terms of methane production of various origins; analysis of the current degree of its use in Poland; identification of factors affecting the use of methane for business purposes in this country.

\section{Method of research}

The following research methods were used in the research: review and analysis of scientific literature; analysis of data published by the Central Statistical Office of Poland, National Agricultural Support Centre of Poland; analysis of data obtained from the Energy Regulatory Office and the State Mining Authority of Poland; environmental interviews. As a result, it was possible to identify the causes of the current situation in renewable energy and to propose solutions that will allow better use of methane obtained from alternative sources for energy purposes

\section{Results of the research and Discussion with the other scientists and papers}

\section{Greenhouse gas emissions in Poland}

Greenhouse gases include carbon dioxide $\left(\mathrm{CO}_{2}\right)$, methane $\left(\mathrm{CH}_{4}\right)$, nitrous oxide $\left(\mathrm{N}_{2} \mathrm{O}\right)$ and industrial gases. Aggregated emissions of these gases are expressed as a $\mathrm{CO}_{2}$ equivalent. Equivalent means one megagram (1 Mg) of carbon dioxide or an amount of other greenhouse gas equivalent to $1 \mathrm{Mg}$ of carbon dioxide, calculated using the appropriate warming factor. The global warming rate is as follows: carbon dioxide - 1 , methane -25 , nitrous oxide - 298 [5].

Greenhouse gas emissions are associated with traditional energy production, industrial processes, product operation, agriculture and municipal waste. The Kyoto Protocol imposes an obligation on individual countries to declare a reduction in greenhouse gas emissions compared to the base year. For Poland, it was 1988, when the emission amounted to 569.8 million $\mathrm{Mg}$. Poland has committed to a $6 \%$ reduction in emissions of this type of gas in 2008-2012 compared to the base year. Already in 2005, national greenhouse gas emissions amounted to 397.7

https://doi.org/10.32933/Actalnnovations.33.9 •ISSN 2300-5599 • C 2019 RIC Pro-Akademia - CC BY 
million Mg and remained almost unchanged until 2016 (in which it amounted to 396 million Mg of carbon dioxide equivalent). This means that compared to the base year there was a decrease in emissions by more than $30 \%$, and thus much larger than declared, despite the increase in Gross Domestic Product (GDP) in this period. The total amount of greenhouse gases emitted to the atmosphere in 2016 was: 321 million $\mathrm{Mg}$ of carbon dioxide, 1.8 million $\mathrm{Mg}$ of methane (46 million $\mathrm{Mg}$ of equivalent) and 65,000 Mg of nitrous oxide (19 million $\mathrm{Mg}$ of the equivalent). Emission of 1.8 million $\mathrm{Mg}$ of methane is about 2.5 billion $\mathrm{Nm}^{3}$, which is about $1 / 6$ of the current domestic consumption of high-methane natural gas. The majority of methane, which is $41 \%\left(1.02\right.$ billion $\left.\mathrm{m}^{3}\right)$, is emitted to the atmosphere in connection with the extraction of fossil fuels (liquid and solid). Other sources include: agriculture with a $30 \%$ share $\left(0.75\right.$ billion $\left.\mathrm{m}^{3}\right)$ and waste $19 \%\left(0.475\right.$ billion $\left.\mathrm{m}^{3}\right)$ [5].

Among greenhouse gases that have such a negative impact on the Earth's atmosphere and cause long-term climate changes, sometimes with catastrophic effects, only methane can be used for energy purposes and benefit the economy.

\section{Firedamp as a source of energy}

Most Polish mines extract hard coal from methane deposits. In Polska Grupa Górnicza Sp. z o.o., which took over 11 mines from Kompania Węglowa S.A. only KWK "Piast-Ziemowit" is a non-methane mine. Methane is the greatest natural threat for miners in hard coal mines. The parameters determining the magnitude of the methane hazard are: "methane content - the volumetric amount of methane of natural origin, contained in a weight unit deep in the coal cathode and absolute methane content, which determines the amount of methane released in relation to the unit of time" [6]. The authors learned from correspondence with the State Mining Authority that the absolute methane content of Polish hard coal mines in 2018 was estimated at 916.05 million $\mathrm{m}^{3}$ of methane. Due to the spontaneous methane extraction in the years 2000-2013, 11 national methane hazards, and one methane and rock outburst occurred in domestic coal mines, resulting in death and injury of several dozen miners [7]. There would be many more events and casualties if the mines did not have methane drainage, "which on the one hand raises mining costs, but on the other hand allows obtaining high quality gas and significantly improves underground work safety" [6].

It should be mentioned that firedamp is not pure methane, but it is a mixture of it with air of varying proportions. It can be burned for the needs of mines (heating and technological), electricity and heat generation in cogeneration systems or sold to external customers. The correspondence of the authors of the article with an employee of the State Mining Authority shows that in 2018, 316.97 million $\mathrm{m}^{3}$ of methane was obtained in the process of methane drainage of mines, which was utilized in $60 \%$.

A good example is "Brzeszcze" coal mine in which methane removal has been carried out since 1976. In 2013, it managed to sell about 37 million $\mathrm{m}^{3}$ of gas to Energetyka Dwory in Oświęcim and about $1.5 \mathrm{~m}^{3}$ to Nadwiślańska Spółka Energetyczna [6]. In order to manage more gas, KWK "Brzeszcze" together with Tauron Group plans to launch two cogeneration installations with a power of $2.7 \mathrm{MWe}$ each by 2021 . Their construction will produce up to $160 \mathrm{MWh} /$ day $(588,400 \mathrm{MWh} /$ year) of electricity and the same amount of heat. It will also be an environmental protection measure and will reduce fees related to methane emissions to the atmosphere. The project implementation is part of the postulates of the Tauron Group Strategic Research Agenda. The installation is carried out by MAGENTA Grupa Tauron [8].

\section{Obtaining biogas from municipal waste landfills}

According to CSO data [5], in 2017, 12 million Mg of municipal waste (9.5\% of all waste) was generated in Poland, of which only $7 \%$ (848 thousand $\mathrm{Mg}$ ) was intended for biological processing - composting or fermentation [9]. The rest was disposed of in municipal waste dumps or incinerated in thermal waste treatment plants.

As already mentioned, natural fermentation processes occur in landfills, causing the release of biogas, which is a product of the anaerobic breakdown of organic substances contained in the waste. The resulting biogas can be used for economic purposes. The Regulation of the Minister of the Environment of 30 April 2013 on waste landfills contains "detailed requirements regarding the location, construction and operation of waste landfills, which correspond to particular types of waste landfills". Paragraph 8.1 states that "a landfill where biodegradable waste is to be stored is equipped with an installation for discharging landfill gas" and the resulting gas "is cleaned and used for energy purposes, and if it is impossible - it burns in a flare" [10]. Biogas collection installations are mounted on specially sealed landfills, built as a well system, to which biogas consisting of $45-65 \%$ methane, 25 $35 \%$ carbon dioxide, $7-10 \%$ nitrogen and up to $3 \%$ oxygen diffuses. From the well, it is sent through a pipe system for development. Biogas is subjected to mechanical treatment, desulphurization and drying [9]. The calorific value of biogas from landfills ranges from $16-24 \mathrm{MJ} / \mathrm{m}^{3}$ of waste.

At large landfills, biogas is burned in cogeneration units generating electricity and heat, the total efficiency of which is up to $80 \%$ [11]. Smaller landfills only use it to generate heat or burn it in torches. Electricity is sold

https://doi.org/10.32933/Actalnnovations.33.9 •ISSN 2300-5599 • C 2019 RIC Pro-Akademia - CC BY 
to the energy network and heat is used to heat water and rooms related to the operation of the landfill. On the other hand, the possibilities of selling heat to external customers are very limited due to the location of storage sites. In 2017, 301 landfills were legally being operated in Poland, of which 267 had degassing installations [12]. An additional advantage of the latter (apart from the energetic use of methane) is the reduction of odours that are burdensome for the inhabitants of the surrounding towns. According to data from the Energy Regulatory Office [13], as of December 31, 2018, only 97 landfills in Poland produced electricity. Table 1 provides information on the number of installations for receiving landfill biogas in individual voivodships, installed generating power and quantities of electricity sold.

Table 1. Power and electricity production form installations at landfills in 2018 in voivodships in Poland

\begin{tabular}{|l|c|r|r|l|}
\hline \multirow{2}{*}{ Voivodship } & \multicolumn{5}{|l|}{ Installations at landfills } \\
\cline { 2 - 5 } & Number & $\begin{array}{l}\text { Power } \\
\text { in MWe }\end{array}$ & $\begin{array}{l}\text { Energy production } \\
\text { in MWhe }\end{array}$ & $\begin{array}{l}\text { Power utilization } \\
\%\end{array}$ \\
\hline Dolnośląskie & 9 & 6.136 & $5,434.796$ & 10.11 \\
\hline Kujawsko-pomorskie & 7 & 3.254 & $8,782.551$ & 30.81 \\
\hline Lubelskie & 3 & 1.428 & 398.304 & 3.18 \\
\hline Lubuskie & 2 & 0.940 & $4,654.656$ & 56.53 \\
\hline Łódzkie & 4 & 3.678 & $16,024.764$ & 49.74 \\
\hline Małopolskie & 6 & 4.260 & $8,071.171$ & 21.63 \\
\hline Mazowieckie & 18 & 9.286 & $26,712.509$ & 32.84 \\
\hline Opolskie & 3 & 1.394 & $1,334.049$ & 10.92 \\
\hline Podkarpackie & 2 & 1.191 & $4,394.879$ & 42.12 \\
\hline Podlaskie & 1 & 0.320 & $1,111.138$ & 39.64 \\
\hline Pomorskie & 6 & 5.359 & $9,083.892$ & 19.35 \\
\hline Śląskie & 15 & 12.055 & $25,938.864$ & 24.56 \\
\hline Świętokrzyskie & 1 & 2.040 & $2,398.770$ & 13.42 \\
\hline Warmińsko-mazurskie & 3 & 1.407 & $2,243.082$ & 18.20 \\
\hline Wielkopolskie & 10 & 7.380 & $7,912.977$ & 12.24 \\
\hline Zachodniopomorskie & 7 & 2.720 & $4,232.822$ & 17.76 \\
\hline Total & 97 & 62.348 & $128,729.224$ & 23.57 \\
\hline & \multicolumn{3}{|l|}{ Source: Elaboration based on $[13]$} & \\
\hline
\end{tabular}

Most of such installations were in the following voivodships: Mazowieckie (18), Śląskie (15), Wielkopolskie (10) and Dolnośląskie (9). Podlaskie and Świętokrzyskie voivodships had one installation each, Lubuskie - two, and Warmińsko-Mazurskie Voivodeship - three. The highest power installations were reported in Śląskie (12,055 $\mathrm{MWe}$ ) and Mazowieckie (9,286 MWe) voivodships. In turn, the smallest power was installed in the Podlaskie Voivodeship (only $0.32 \mathrm{MWe}$ ).

These installations produced a total of about 129 GWh of electricity, including the most - in Mazowieckie and Śląskie voivodships, and the least - in Lubelskie. The low number of electricity producing storage sites may be due to the fact that with the current price of energy sold to the network and low rates of utilization of installed power, local governments do not decide to invest in power generators, as it is unprofitable. The low utilization of installed power does not, however, disqualify installations for the recovery of methane from landfills, because their most important goal is to reduce methane emissions to the atmosphere.

\section{Biogas production in sewage treatment plants}

Important tasks of local governments in Poland include water supply and sewage management. Municipal sewage is "domestic sewage or a mixture of domestic sewage with industrial wastewater, rainwater or snowmelt, discharged with devices used to carry out the commune's own tasks in the field of sewage and municipal wastewater treatment". Their treatment takes place in specially designated plants - municipal sewage treatment plants, the number of which in 2000-2017 increased from 2,417 to 3,258 (increase by $34.78 \%$ ) [5].

The full cycle of municipal wastewater treatment includes: mechanical, chemical and biological treatment as well as removal of nutrients (nitrogen and phosphorus compounds). New and modernized municipal sewage treatment plants are in $75 \%$ equipped with installations for biological treatment and $25 \%$ for increased removal 
of nutrients. The equipment of the sewage treatment plant with installations for biological treatment and removal of nutrients has significantly improved the purity of water in Polish rivers. In sewage treatment plants, however, sewage sludge management is a problem. The best way is to subject them to methane fermentation, resulting in biogas containing up to $70 \%$ methane [14]. The limitation of the methane fermentation process is the low level of degradation of the organic substance and the long residence time of the sludge in the reactor. Therefore, improving efficiency requires preliminary disintegration of the sludge and enriching it with organic matter contained, e.g. in waste from the food industry or kitchen waste, which would be crushed in grinders installed at the sinks. The effect of the latter would be the reduction in the content of organic substances in mixed municipal waste, directed to landfills.

Some municipal sewage treatment plants have biogas installations and devices for burning it in cogeneration aggregates producing electricity and heat. The former is sold to the network and the latter is intended to support the methane fermentation process in about $30 \%$. The remaining part is used for the needs of the sewage treatment plant and possible selling. As of December 31, 2018, only 109 municipal sewage treatment plants from amongst 3,257 (mechanical - 8, biological -2,439, with increased removal of nutrients - 810) produced electricity $[15,16]$. This means that electricity from biogas is produced only by around $3 \%$ of municipal treatment plants, and while $75 \%$ of treatment plants could do that. For comparison: in Germany per 10,000 sewage treatment plants, 1,200 have already biogas plants. They produce totally so much electricity that it would be enough for 300,000 households [17]. Table 2 provides information on the number of biogas plants in Poland, installed capacity, amount of electricity sold, broken down by voivodships.

Table 2. Power and electricity production in installations at sewage treatment plants in 2018 in voivodships in Poland

\begin{tabular}{|l|c|r|r|r|}
\hline \multirow{2}{*}{ Voivodship } & \multicolumn{5}{|l|}{ Installations in sewage treatment plants } \\
\cline { 2 - 5 } & Number & Power in MWe & $\begin{array}{c}\text { Energy production } \\
\text { in MWhe }\end{array}$ & $\begin{array}{c}\text { Power utilization } \\
\text { in } \%\end{array}$ \\
\hline Dolnośląskie & 9 & 3.702 & $19,272.72$ & 59.43 \\
\hline Kujawsko-pomorskie & 5 & 4.251 & $14,056.36$ & 37.75 \\
\hline Lubelskie & 4 & 2.642 & $17,590.33$ & 76.00 \\
\hline Lubuskie & 2 & 1.190 & $2,618.58$ & 25.12 \\
\hline tódzkie & 5 & 4.204 & $3,932.84$ & 10.68 \\
\hline Małopolskie & 10 & 4.903 & $19,754.48$ & 45.99 \\
\hline Mazowieckie & 14 & 11.254 & $29,797.05$ & 30.22 \\
\hline Opolskie & 3 & 1.252 & $5,661.33$ & 51.62 \\
\hline Podkarpackie & 10 & 3.313 & $11,054.81$ & 38.09 \\
\hline Podlaskie & 5 & 4.112 & $20,065.26$ & 55.70 \\
\hline Pomorskie & 5 & 6.897 & $22,703.32$ & 37.58 \\
\hline Śląskie & 18 & 9.673 & $35,906.95$ & 42.38 \\
\hline Świętokrzyskie & 2 & 0.982 & $3,613.32$ & 42.00 \\
\hline Warmińsko-mazurskie & 6 & 3.791 & $12,671.09$ & 38.16 \\
\hline Wielkopolskie & 7 & 6.637 & $25,013.56$ & 43.02 \\
\hline Zachodniopomorskie & 4 & 1.478 & $5,731.00$ & 44.26 \\
\hline Total & 109 & 70.281 & $249,443.00$ & 40.52 \\
\hline & \multicolumn{2}{|c|}{ Source: Elaboration based on $[13]$} & \\
\hline
\end{tabular}

In 2018, all sewage treatment plants produced about $250 \mathrm{GWh}$ of electricity in total. Most biogas plants producing electricity from wastewater were located in Śląskie (18) and Mazowieckie (15) voivodeships, which is associated with a large number of inhabitants and a high degree of urbanization. The least amount of them function in the following voivodships: Świętokrzyskie (2), Lubuskie (2) and Opolskie (3). In terms of energy generated, the leading voivodships: Śląskie, Mazowieckie and Wielkopolskie.

Analysis of the data contained in Tables 1 and 2 provides grounds to conclude that the utilization of installed power at sewage treatment plants is much higher than at waste landfills; on the other hand there is no data on the use of heat. Only by observing the location of the sewage treatment plant in Krakow it can be assumed that it is higher compared to waste landfills. The heat is used to heat the technical facilities of the treatment plant. The surrounding plants also receive heat generated in the wastewater treatment plant. 
The conducted interviews show that the profitability of municipal sewage treatment plants is not impressive at present time. Perhaps the introduction of special certificates (similar to green certificates) for electricity obtained from biogas (from sewage treatment plants) would increase the interest of local governments in the installation of power generators.

It is worth to remind that the Tradable Green Certificates system (TGCs) or Tradable Renewable Energy Certificates (TREC) is a mechanism to support the production of energy from renewable sources, which was introduced on October 1, 2005, pursuant to the amended Act of April 10, 1997 Energy Law [18]. Green certificates are documents that confirm the production of electricity using geothermal energy, solar, wind, water (waves, currents and tides as well as rivers fall) or obtained from biomass. Certificate trading was organized on the Polish Power Exchange (TGE) on the Property Rights Market [19]. The essence of the TGCs system is imposed on energy companies dealing in the sale of electricity to end users, the obligation to have the number of green certificates specified by the President of the Energy Regulatory Office. The company can generate the applicable amount of energy from renewable energy sources (RES), it can also buy green certificates on the free market or pay so called "substitution fee".

\section{Agricultural biogas as a source of energy}

The Act on renewable energy sources (adopted by the Sejm of the Republic of Poland on February 20, 2015) defines agricultural biogas as "fuel obtained in the methane fermentation process from agricultural raw materials, agricultural by-products, liquid or solid animal excrements, by-products or residues from the processing of agricultural products or biomass forest, excluding gas derived from raw materials from sewage treatment plants and landfills. "It is produced in biogas plants consisting of a complex of buildings adapted to convert the above-mentioned raw materials (substrates) into biogas and digestate which is a valuable fertilizer [20].

Agricultural biogas contains $40-85 \%$ of methane, $16-48 \%$ of carbon dioxide, $0.6-7.5 \%$ of nitrogen [21]. After removal of hydrogen sulphide, carbon dioxide and water vapor, it is most often burned in cogenerators. The main advantage of combined electricity and heat generation is a much higher overall efficiency of this process compared to separate generation (Figure 1). When heat and energy is generating separately, 156 units of fuel are needed to produce 34 units of electricity and 56 units of heat. However, with cogeneration combustion, 100 fuel units are enough to get the same result. This means that the total efficiency of cogeneration aggregates is about $90 \%$, and the efficiency of separate production of electricity and heat is only $58 \%$. Obtaining such high efficiency is possible due to the use of heat recovery generated in the process of electricity production [22]. 


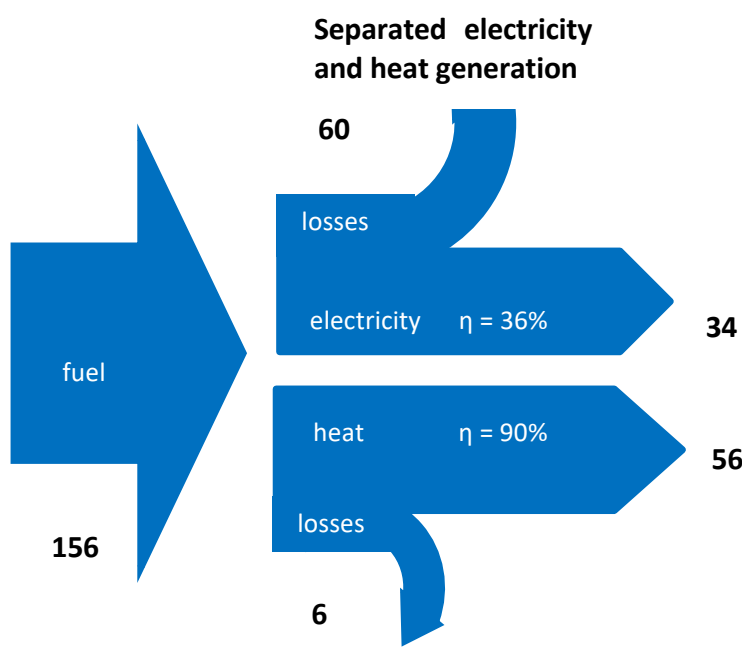

total efficiency $58 \%$
Electricity and heat energy generation in cogeneration units

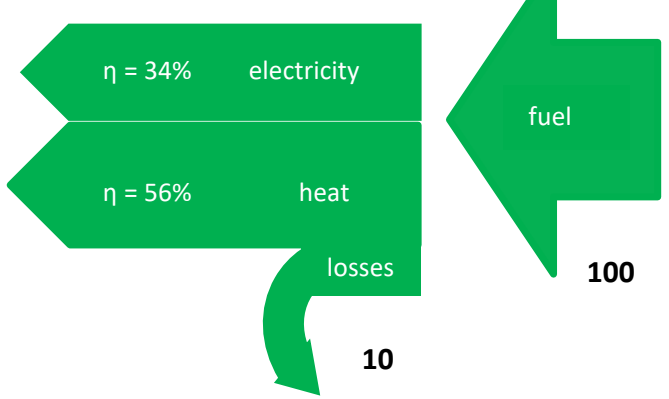

total efficiency $\mathbf{9 0 \%}$

Figure 1. Comparison of efficiency of electricity and heat generation in a separated process and in cogeneration units, Source: [22]

Agricultural biogas plants can be an important element of the national energy policy implemented in rural areas where agricultural production and breeding (cultivation of crop plants, animal husbandry) and forest management are carried out. The estimated raw material potential in these areas allows for the production of about 5 billion $\mathrm{m}^{3}$ / year of agricultural biogas with high-methane natural gas parameters [23]. Considering this potential, in 2010 the Council of Ministers adopted a document entitled "Directions of development for agricultural biogas plants in Poland for the years 2010-2020" [24], in which it was assumed that by 2020, on average, one biogas plant will operate in each commune. Meanwhile, only 95 of such biogas plants operated at the end of 2018. Table 3 summarizes data on their number in individual voivodships, installed power and amount of electricity produced.

Table 3. Power and electricity production of agricultural biogas plants in 2018 in voivodships in Poland

\begin{tabular}{|c|c|c|c|c|}
\hline \multirow[b]{2}{*}{ Voivodship } & \multicolumn{4}{|c|}{ Agricultural biogas plants } \\
\hline & Number & $\begin{array}{l}\text { Power in } \\
\mathrm{MW}_{\mathrm{e}}\end{array}$ & $\begin{array}{l}\text { Energy production in } \\
\mathrm{MWh}_{\mathrm{e}}\end{array}$ & $\begin{array}{l}\text { Power utilization } \\
\text { in } \%\end{array}$ \\
\hline Dolnośląskie & 10 & 9.410 & $33,808.488$ & 41.01 \\
\hline Kujawsko-pomorskie & 6 & 7.991 & $49,974.044$ & 71.39 \\
\hline Lubelskie & 7 & 9.859 & $55,906.743$ & 64.73 \\
\hline Lubuskie & 4 & 2.792 & $18,366.557$ & 75.09 \\
\hline Łódzkie & 4 & 5.057 & $35,943.210$ & 81.14 \\
\hline Małopolskie & 2 & 1.150 & $9,555.870$ & 94.86 \\
\hline Mazowieckie & 6 & 6.819 & $24,181.135$ & 40.48 \\
\hline Opolskie & 1 & 2.000 & $7,604.988$ & 43.41 \\
\hline Podkarpackie & 3 & 2.498 & $11,067.572$ & 50.58 \\
\hline Podlaskie & 9 & 7.596 & $30,189.763$ & 45.37 \\
\hline Pomorskie & 9 & 10.159 & $79,996.491$ & 89.89 \\
\hline Śląskie & 2 & 1.596 & $11,638.826$ & 83.25 \\
\hline Świętokrzyskie & 1 & 0.800 & $3,403.420$ & 48.56 \\
\hline Warmińsko-mazurskie & 10 & 9.606 & $69,043.861$ & 82.05 \\
\hline Wielkopolskie & 11 & 10.678 & $54,105.624$ & 57.84 \\
\hline Zachodniopomorskie & 13 & 12.690 & $72,311.543$ & 65.05 \\
\hline Total & 95 & 102.688 & $567,099.135$ & 63.04 \\
\hline
\end{tabular}


The majority of biogas plants in 2018 operated in the following voivodeships: Zachodniopomorskie (13), Wielkopolskie (11), Dolnośląskie (10) and Zachodniopomorskie (10). One biogas plant operated in Opolskie and one in Świętokrzyskie voivodship, and two in either Małopolskie and Śląskie. The total installed power of all agricultural biogas plants in Poland amounted to $102.688 \mathrm{MW}$ then. In total, biogas plants produced about 570 GWh of electricity, the majority - in the Pomeranian, Warmińsko-Mazurskie, Lublin and Wielkopolskie voivodships. Biogas plants from Małopolskie, Śląskie and Warmińsko-Mazurskie Voivodeships showed the highest factor of utilization of installed power. As for the use of power in agricultural biogas plants, it is much higher than in installations at landfills and municipal wastewater treatment plants.

Cogenerated biogas produces more heat than electricity. In the years 2011-2014 and until mid-2015, agricultural biogas producers were required to provide information on the amount of heat produced. According to the data of the National Agricultural Advisory Centre [25], the amount of heat produced at that time was as follows: 2011 - 82.628 GWh, 2012 - 160.128 GWh, 2013 - 246.557 GWh, 2014 - 373.906 GWh and in the first half of 2015 $224.996 \mathrm{GWh}$.

There are several reasons why the agricultural biogas production potential is not being used. The most important reason is the lack of places in local spatial development plans of communes for the location of new biogas plants, therefore the time for obtaining a building permit is extended, mainly because of residents' protests. The reason for the protests is primarily that biogas plants are a potential source of odour emissions and should be located away from residential buildings [26].

The factor limiting the creation of new agricultural biogas plants is also the lack of prospects for stable conditions of implementing investments, primarily in terms of the amount, length and form of financial support. In addition, in recent years there has been a decline in the prices of certificates of origin for energy from renewable energy sources (the so-called green certificates) listed on the Polish Power Exchange (TGE - in Polish: Towarowa Giełda Energii). In the years 2011-2015, prices of certificates of origin dropped from PLN 280 to PLN 120. As a result, the biogas plant revenues decreased from PLN 480 to PLN 300 / MWh, which was the border price for profitability [27].

Blue certificates were introduced in Poland due to the Act on Renewable Energy Sources, which entered into force on 1 July 2016 [28], in order to support the development of biogas energy production in Poland. The support mechanism is based on the commitment of energy companies to buy parts of electricity produced in agricultural biogas plants. If the energy companies do not have such a possibility, they are obliged to purchase so-called "Blue certificates" directly from biogas plant owners or on the Polish Power Exchange (TGE ).

\section{Uncertainty and impact of research results on science, economy, environment and society}

It is known that business activity involves many types of risk as a result of uncertainty arising from the external environment. Waste management allows reducing the impact of ecological risk primarily on human health and life. However, their rational use also allows for obtaining economic effects, e.g. in the form of obtained biogas, which can be used for the production of electricity and heat.

Waste management activities are part of the new economy model - the Circular Economy, which is implemented in the member states of the European Union. The model is focused on reproducibility and renewal, and the main effects of its implementation are the rationality of management and reduction of negative impact on the natural environment.

Increasing amounts of waste generated by individual countries pose a threat to the flora and fauna of our planet. In addition, a large part of the waste is unused raw materials that can return to the economy. For example, the substrates used as input in agricultural biogas plants are agricultural and food waste. Sewage treatment plants obtain biogas from waste waters. Biogas can also be a by-product of operations, such as mine gas escaping during coal mining, or gas generated in municipal waste landfills.

Technologies for capturing or obtaining methane in the process of anaerobic waste fermentation are a new direction of scientific research that will bring measurable benefits to humanity, such as the development of more efficient waste treatment methods that the Earth's inhabitants constantly produce.

Biogas is pure or purified methane. On the one hand, the use of methane for energy purposes benefits the economy, it is used for the production of electricity and heat, and as fuel for driving vehicles. On the other hand, methane is a greenhouse gas that contributes to climate change with all its negative effects, including extremely

https://doi.org/10.32933/Actalnnovations.33.9 • ISSN 2300-5599 • C 2019 RIC Pro-Akademia - CC BY 
low or high temperatures, drought, hurricanes, storms, floods, melting glaciers, rising temperature and ocean water levels, flooding low-lying territories, spreading infectious diseases, climate migrations, political tensions. Therefore, reducing methane emissions to the atmosphere through its management is a pressing challenge for science and the economy.

\section{Summary and conclusions}

As it results from the data cited in tables 1-3, in 2018, 945 GWh of electricity was generated from biogas in Poland. This result was $18 \%$ higher compared to 2014 ( $800 \mathrm{GWh}$ ). However, this increase is far from sufficient to meet the obligations regarding the share of renewable energy in the Polish energy mix. For example, in Germany already in 2014, 86,062 GWh of electricity was produced from biogas [29].

The construction of installations for the production of energy from biogas obtained at landfills and in municipal wastewater treatment plants requires high expenditures, the return of which is very slow, due to the low power utilization of installed cogeneration aggregates. An incentive to invest in these installations could be the granting of blue certificates for energy produced from any type of biogas.

In addition, the development of agricultural biogas plants is currently limited by the protests of residents who are afraid of emissions of substances harmful to health (hydrogen sulphide, ammonia, mercaptans, carbon monoxide). Limiting the odour nuisance of agricultural biogas plants means building them at a sufficiently large distance from human settlements, using substrates with less odour nuisance, encapsulation of lines and production rooms, purifying waste gases, using: biofilters, bioscrubbers, bioflushers, physical-chemical methods, ozonation, UV radiation exposure [23]. The fact that this is a problem that can be solved is demonstrated by the large number of such biogas plants in Germany, where the population density is much higher than in Poland.

Producers and distributors of electricity and heat should be more widely involved in the use of methane from unconventional sources for energy purposes. Currently only ENEA Wytwarzanie Sp. z o.o. operates two agricultural biogas plants. They are located in Liszków (Kujawsko-Pomorskie Voivodeship) and Gorzesław (Dolnośląskie Voivodeship). Their installed power is $2.126 \mathrm{MW}$ and $1.698 \mathrm{MW}$, respectively [22]. However it is most important that the state's energy policy is aimed at supporting the energy use of methane from alternative sources, for the benefit of the economy and the environment.

\section{References}

[1] B.Zaporowski, Zrównoważony rozwój źródeł wytwórczych energii elektrycznej”. Polityka energetyczna, tom 19, zeszyt 3, 2016, s. 35-48.

[2] https://ec.europa.eu/clima/policies/strategies/2030_pl (Access: 13.01.2020)

[3] https://ec.europa.eu/clima/policies/strategies/2050_pl (Access: 13.01.2020)

[4] https://op.europa.eu/fr/publication-detail/-/publication/92f6d5bc-76bc-11e9-9f0501aa75ed71a1/language-en (Access: 13.01.2020)

[5] Ochrona środowiska 2018, GUS, Warszawa, 2018.

[6] A. Musiał, Z. Kokesz, Metan wiodącym zagrożeniem naturalnym w KWK „Brzeszcze”, Górnictwo odkrywkowe, $\mathrm{nr}$ 56, 2015, s. 62-66.

[7] Z. Rawicki, D. Katan, Badania i rozwój nauki skuteczną drogą do poprawy bezpieczeństwa pracy w kopalniach, Przegląd górniczy, nr 2, 2015, s. 58-65.

[8] www.biznesalert.pl/metan-brzeszcze-energia-cieplo (Access: 10.06.2019)

[9] K. Jankowski i inni, Rozwój technologii w zakresie utylizacji odpadów komunalnych, Zeszyty Naukowe Uniwersytetu Przyrodniczo-Humanistycznego w Siedlcach, nr 102, 2014, s. 9-19.

[10] Rozporządzenie Ministra Środowiska z dnia 30 kwietnia 2013 roku w sprawie składowisk odpadów (Dz. U. 2013).

[11] A. Otawa, W. Skomudek, Wpływ aktualnych uwarunkowań rynku gazu w Polsce na bezpieczeństwo energetyczne i rozwój gazowych jednostek ko generacyjnych, Logistyka, nr 6, 2014, s. 8240-8249.

[12] www.forbes.pl/gospodarka/odpady-komunalne-i-wysypiska-smieci-w-2017-r-w-polsce/j48mtvg (Access: 10.06.2019).

[13] Pismo DSK-WKS.056.30.2019.IRŚ. 2019. Urząd Regulacji Energetyki, 07.03.2019

[14] E. Neczaj Ewa, Metody intensyfikacji produkcji biogazu z komunalnych osadów ściekowych, Politechnika Częstochowska. Seria Monografie, nr 309, Częstochowa 2016.

[15] Pismo DSK-WKS.056.32.2019.IRŚ. 2019. Urząd Regulacji Energetyki, 21.03.2019

[16] www.bdl.stat.gov.pl/ (Access: 13.09.2019)

[17] http://www.chronmyklimat.pl/projekty/biogazownia-przemyslany-wybor/wiadomosci/5/bedzie-szybciejprzybywac-biogazowni-przy-oczy

[18] http://prawo.sejm.gov.pl/isap.nsf/DocDetails.xsp?id=WDU20190000755 
[19] tge.pl/property-rights-prm

[20] A. Ostrowska, Prawno-administracyjne bariery budowy biogazowni rolniczych w Polsce, Acta Universitatis Lodziensis. Folia Oeconomica, nr 270, 2012, s. 127-135.

[21] Biogaz rolniczy odnawialne źródło energii - teoria i praktyczne zastosowanie” pod red. Witolda Podkówki, Powszechne Wydawnictwo Rolnicze i Leśne. Warszawa, 2012.

[22] www.argoxee.com.pl/kogeneracja.php (Access: 10.06.2019)

[23] A. Piwowar, M. Dzikuć, Charakterystyka podmiotów zajmujących się wytwarzaniem biogazu rolniczego w Polsce, Journal of Agrobusiness and Rural Development, nr 1(27), 2013, s. 207-217.

[24] Kierunki rozwoju biogazowi rolniczych w Polsce w latach 2010-2020, Dokument Rady Ministrów, 2010.

[25] www.kowr.gov.pl/uplods/pliki/oze/biogaz/Rejestr wytwórców biogazu rolniczego (Access: 12.09.2019)

[26] K. Klemba, Biogazownia jako potencjalne źródło zagrożeń emisjami odorowymi oraz działania prewencyjne, Eliksir, nr 2, 2015, s. 22-27.

[27] A. Curkowski, A. Oniszk-Popławska, A. Haładyj, Biogazownia - przemyślany wybór. Co powinien wiedzieć każdy obywatel, Fundacja instytutu na rzecz Ekorozwoju. Warszawa, 2013.

[28] http://prawo.sejm.gov.pl/isap.nsf/download.xsp/WDU20160000925/O/D20160925.pdf

[29] www.gramwzielone.pl/bioenergia/26368/trzy-kraje-zdominowaly-produkcje-biogazu-w-europie (Access: 10.06.2019). 